\title{
Influence of water extract viscosity and exogenous enzymes on nutritive value of rye hybrids in broiler diets *
}

\author{
Danuta Boros' ${ }^{1}$ and M. R. Bedford ${ }^{2}$ \\ 'Laboratory of Nutritional Evaluation of Plant Materials, Institute of Plant Breeding \\ Radzików, 05-870) Blonie, Poland \\ 'Finnfeeds International Ltd, Ailesbury Court \\ High Street, Marlborough, Wiltshire SN8 IAA, UK
}

(Received 19 April 1999; accepted 7 October 1999)

\begin{abstract}
Broiler chickens were fed diets based on four hybrids of rye varying in viscosity of grain water extract (WEV). These diets were prepared with or without arabinoxylan degrading enzymes to study the effect of grain viscosity and xylanase and arabinosidase supplementation on growth rate and feed efficiency, metabolisable energy ( $\mathrm{AME}_{11}$ ), apparent retention of protein (APR) and digestibility of arabinoxylans in young broiler chickens. A wheat-based diet was used as a control. Elimination of the detrimental effect of soluble arabinoxylans (SAX) by the addition of both enzymes significantly improved the feed intake, weight gain and feed to gain ratio, on average by 30,57 , and $21 \%$, respectively, as compared with the results of birds fed the corresponding unsupplemented diets. These improvements were achieved as a result of improvement in $A M E_{n}, A P R$, and digestibitity of soluble and total arabinoxylans by $5,8,45$ and $34 \%$, respectively. In general, the poorer the nutritive value of the tested rye, the greater the benefit following enzyme supplementation. The results of this study showed that it is possible to improve the nutritive value of rye for broiler chickens by selection and brecding of rye varieties with a lower WEV and SAX content logether with the appropriate choice of feed enzymes that can hydrolyse and thus lower the viscosity of gut digesta and increase retention of nutrients.
\end{abstract}

KEY WORDS: rye, viscosity, soluble arabinoxylans, exogenous enzymes, nutrient retention, broiler chickens

\footnotetext{
* Supported by the State Committee for Scientific Research, Grant No PB 610/P06/95/08
} 


\section{INTRODUCTION}

Rye is rich in soluble arabinoxylans that are highly viscous and have significant water holding properties. Since high viscosity of arabinoxylans affects the digestion and absorption of all nutrients, rye is not habitually used as a cereal component in broiler diets. The beneficial effect of pentosanase (xylanase) addition on growth rate and feed efficiency of broiler chickens fed diets containing rye is well documented. However, the performance of chickens fed xylanase-supplemented rye-based diets is still not satisfactory as compared with chickens fed corresponding wheat- or barley-enzyme-supplemented diets (Bedford et al., 1991, 1995; Friesen et al., 1991; Boros et al., 1995). These results might suggest that the enzymes used in these studies were not able to sufficiently hydrolyse the arabinoxylans in rye and eliminate their viscosity and associated capacity to absorb water. It is worth mentioning that perhaps the arabinose side chains in rye are more apparent than in wheat and thus responsible for reducing the efficacy of xylanase, which may explain why xylanase addition has not allowed rye to compete with wheat. Additionally, this also indicates that in the case of a rye diet a broader spectrum of exogenous enzymes, possibly including arabinofuranosidases, is needed to alleviate the detrimental effect of rye arabinoxylans.

Moreover, genotype and environment have been shown to influence the concentration and quality of arabinoxylans in rye and also the efficacy of the pentosanases used (Madej et al., 1990; Campbell et al., 1991; Bengtsson et al., 1992). It has also recently been found that WEV correlated significantly with the growth and performance of young broilers fed rye diets (Boros et al,, 1997). Rye hybrids selected for a lower WEV and SAX content showed a high nutritive value for broilers, similar to the nutritive value of wheat (Boros, 1998). Thus, it seems that a selection and breeding program directed towards lower viscosity of grain water extract and subsequent better nutritive quality, together with the selection of appropriate feed enzymes possessing not only exo- and endoxylanase but also arabinofuranosidase activities may considerably increase the utilisation of rye in poultry nutrition.

The purpose of the study was to determine the effect of xylanase and arabinosidase supplementation of diets containing four rye hybrids varying in WEV on growth performance and metabolisable energy values in young broiler chickens. The apparent retention of protein and digestibility of arabinoxylans from rye hybrid based diets were also determined.

\section{MATERIAL AND METHODS}

\section{Cereals}

Four rye hybrids (three-way crosses) varying in WEV were selected for this study. Wheat, var. Almari was used as a control. All cereal grains represented winter forms and were grown under similar soil-climate conditions in Radzików (Poland). 


\section{Diets and growth trial}

The growth trial in a $4 \times 2$ factorial design ( 4 rye varieties $\times 2$ enzymes) was carried out on 72 one-week-old cockerels (ISA 215) with an average initial weight of $84.3 \pm 4.6 \mathrm{~g}$, kept in individual cages. Each group had eight replicates with one bird per replicate. The diets were formulated to meet the requirements of broiler chickens (Table 1). The rye diets were supplemented with $1 \mathrm{~g} / \mathrm{kg}$ of commercial xylanase preparation, which contained ground wheat as a carrier and $0.2 \mathrm{ml} / \mathrm{kg}$ of arabinosidase in a liquid form. The experimental diets were prepared as a mash and fed to the birds for a period of 7 days. Birds had free access to feed and water during the experiment and were exposed to constant light. Each time before weighing chickens were fasted for $4 \mathrm{~h}$. Excreta samples were collected quantitatively over a $72 \mathrm{~h}$ period during 4-7 days of the experiment for determination of apparent metabolisable energy ( $\mathrm{AME}_{\mathrm{n}}$ ) and apparent protein retention (APR) (Hill et al., 1960), then were pooled for evaluation of arabinoxylan digestibility. The $\mathrm{AME}_{\mathrm{n}}$ of the cereals was calculated from the $\mathrm{AME}_{\mathrm{n}}$ of the diets assuming an additive model for the diet ingredients. The following growth performance criteria were evaluated: feed intake, body weight gain (BWG) and feed to gain ratio (FCR).

TABLE 1

Composition of experimental diets, $\mathrm{g} / \mathrm{kg}$

\begin{tabular}{|c|c|c|c|c|c|}
\hline \multirow[b]{2}{*}{ Ingredient } & \multirow{2}{*}{$\begin{array}{l}\text { Wheat } \\
\text { Almari }\end{array}$} & \multicolumn{4}{|c|}{ Rye hybrids } \\
\hline & & $\begin{array}{c}(2713 \times 4475) \\
\times 705\end{array}$ & $\begin{array}{c}(1993 \times 4475) \\
\times 2803\end{array}$ & $\begin{array}{c}(4475 \times 2035) \\
\times 2803\end{array}$ & $\begin{array}{c}(2040 \times 4475) \\
\times 2803\end{array}$ \\
\hline Wheat & 700 & & & & \\
\hline Rye & & 700 & 700 & 700 & 700 \\
\hline $\begin{array}{l}\text { Soyabean protein } \\
\text { concentrate }(64 \% \mathrm{CP})\end{array}$ & 195 & 215 & 215 & 215 & 215 \\
\hline Vegetable fat & 20 & 30 & 30 & 30 & 30 \\
\hline Calcium carbonate & 19 & 18.6 & 18.6 & 18.6 & 18.6 \\
\hline Dicalcium phosphate & 12.6 & 13.2 & 13.2 & 13.2 & 13.2 \\
\hline Vitamin mix & 5 & 5 & 5 & 5 & 5 \\
\hline Mineral mix & 5 & 5 & 5 & 5 & 5 \\
\hline DL-methionine & 3.62 & 3.99 & 3.99 & 3.99 & 3.99 \\
\hline Wheat starch & 39.78 & 9.21 & 9.21 & 9.21 & 9.21 \\
\hline \multicolumn{6}{|c|}{ Estimated nutrient content, $\%$} \\
\hline protein & 21.52 & 21.53 & 21.66 & 21.44 & 21.27 \\
\hline lysine & 1.35 & 1.48 & 1.48 & 1.48 & 1.48 \\
\hline Met + Cys & 0.93 & 0.93 & 0.93 & 0.93 & 0.93 \\
\hline
\end{tabular}




\section{Chemical analyses}

Prior to analysis all samples were ground to a particle size less than $0.5 \mathrm{~mm}$. Dry matter content was determined by drying the samples at $105^{\circ} \mathrm{C}$ for $20 \mathrm{~h}$, protein $(\mathrm{N} \times 6.25)$ by the Kjeldahl method using a Tecator semiautoanalyzer (AOAC, 1990). Dietary fibre fractions: soluble (SDF), insoluble (IDF), and total (TDF) were measured by the gravimetric method of Asp et al. (1983). Arabinoxylans werc determined as aldononitrile acetates by gas liquid chromatography according to McGinnis (1982) after hydrolysis with $1 \mathrm{M}$ fluoroacetic acid (TFA) at $125^{\circ} \mathrm{C}$ for $1 \mathrm{~h}$. Viscosity of the grain water extract (WEV) was measured after a $0.5 \mathrm{~g}$ sample was shaken with $5 \mathrm{ml}$ of distilled water for a period of one $\mathrm{h}$ at $30^{\circ} \mathrm{C}$ and centrifuged for $10 \mathrm{~min}$ at $10000 \mathrm{xg}$. A Brookfield Cone/Plate Digital Viscometer, model LVDV-II+ (Stoughton, MA), with a $0.8^{\circ}$ cone spindle and shear rate of $450 \mathrm{sec}^{-1}$ at $30^{\circ} \mathrm{C}$ was used (Boros et al., 1993). Gross energy of feed and excreta samples was analysed using an adiabatic oxygen bomb calorimeter (KL-11, Mikado, PL). Benzoic acid was used as a standard to calibrate the calorimeter. All analyses were performed either in duplicate or triplicate and expressed on dry matter basis.

The data were subjected to two-way analysis of variance to determine the effect of enzyme supplementation. Comparisons between the wheat- and the rye-containing diets were accomplished through use of Duncan's multiple range test (Duncan, 1955). The results were considered statistically significant at $\mathrm{P} \leq 0.05$.

\section{RESULTS AND DISCUSSION}

The results of chemical analyses are shown in Table 2 . The protein content did not differ markedly between rye hybrids, ranging from 12.1 to $12.7 \%$ and on the average was 2 percentage units lower than that of the control wheat (14.4\%). Similarly the variability of TDF and the arabinoxylan content were low, and did not exceed $10 \%$ in tested rye hybrids, ranging from 14.7 to $15.8 \%$ and from 6.7 to $7.6 \%$, respectively. Within rye hybrids the greatest differences were found in WEV (4.4 to $6.5 \mathrm{mPa} . \mathrm{s}$ ). This quality feature was highly affected by the content of SDF $(\mathrm{r}=0.96)$ and to a lesser extent by the content of SAX $(r=0.60)$. It is noteworthy that greater WEV values of rye hybrids were a result of more viscous arabinoxylans rather than a greater content of SAX as suggested by the higher ratio of WEV to SAX content in such varieties. This may indicate differences in the structure of solublc arabinoxylans, associated with differences in physicochemical properties and, in turn, with the nutritive value of rye (Bengtsson et al., 1990; Girhammar and Nair, 1992; Vinkx et al., 1993, 1995; Vinkx and Delcour, 1996). 
TABLE 2

Physicochemical characteristic of wheat and hybrids of ryc, \% DM

\begin{tabular}{|c|c|c|c|c|c|}
\hline \multirow[b]{2}{*}{ Ingredient } & \multirow{2}{*}{$\begin{array}{l}\text { Wheat } \\
\text { Almari }\end{array}$} & \multicolumn{4}{|c|}{ Rye hybrids } \\
\hline & & $\begin{array}{c}(2713 \times 4475) \\
\times 705\end{array}$ & $\begin{array}{c}(1993 \times 4475) \\
\times 2803\end{array}$ & $\begin{array}{c}(4475 \times 2035) \\
\times 2803\end{array}$ & $\begin{array}{c}(2040 \times 4475) \\
\times 2803\end{array}$ \\
\hline Dry matter & 90.11 & 89.10 & 89.12 & 89.02 & 89.10 \\
\hline Protein & 14.36 & 12.49 & 12.69 & 12.34 & 12.08 \\
\hline $\begin{array}{c}\text { Dietary fibre } \\
\text { soluble } \\
\text { insoluble } \\
\text { total }\end{array}$ & $\begin{array}{r}1.48 \pm 0.12 \\
8.57 \pm 0.09 \\
10.05 \pm 0.14\end{array}$ & $\begin{array}{r}3.92 \pm 0.05 \\
11.88 \pm 0.05 \\
15.80 \pm 0.03\end{array}$ & $\begin{array}{c}4.06 \pm 0.11 \\
10.64 \pm 0.30 \\
14.70 \pm 0.32\end{array}$ & $\begin{array}{r}4.13 \pm 0.14 \\
11.59 \pm 0.20 \\
15.72 \pm 0.22\end{array}$ & $\begin{array}{c}4.66 \pm 0.13 \\
10.72 \pm 0.14 \\
15.38 \pm 0.26\end{array}$ \\
\hline $\begin{array}{l}\text { Arabinoxylans } \\
\text { soluble } \\
\text { insoluble } \\
\text { total }\end{array}$ & $\begin{array}{l}0.88 \pm 0.02 \\
3.75 \pm 0.03 \\
4.63 \pm 0.02\end{array}$ & $\begin{array}{l}2.23 \pm 0.00 \\
5.32 \pm 0.27 \\
7.55 \pm 0.27\end{array}$ & $\begin{array}{l}2.27 \pm 0.07 \\
4.41 \pm 0.07 \\
6.68 \pm 0.14\end{array}$ & $\begin{array}{l}2.09 \pm 0.05 \\
4.88 \pm 0.30 \\
6.98 \pm 0.26\end{array}$ & $\begin{array}{l}2.37 \pm 0.09 \\
4.49 \pm 0.05 \\
6.86 \pm 0.04\end{array}$ \\
\hline $\begin{array}{l}\text { SA: SX ratio } \\
\text { WEV, mPa.S } \\
\text { WEV/mg SAX }\end{array}$ & $\begin{array}{l}0.73 \\
1.08 \\
0.12\end{array}$ & $\begin{array}{l}0.66 \\
4.39 \\
0.20\end{array}$ & $\begin{array}{l}0.68 \\
5.36 \\
0.24\end{array}$ & $\begin{array}{l}0.70 \\
5.34 \\
0.26\end{array}$ & $\begin{array}{l}0.68 \\
6.53 \\
0.28\end{array}$ \\
\hline
\end{tabular}

SA: SX - soluble arabinose to soluble xylose ratio

WEV - viscosity of grain water extract

SAX - soluble arabinoxylans

There were significant differences between the groups fed rye hybrids $(\mathrm{P} \leq 0.001)$ in BWG and FCR which varied from 85 to $57 \mathrm{~g}$ per 7 days and 1.66 to $1.98 \mathrm{~kg} / \mathrm{kg}$, respectively (Table 3 ). The group fed the rye variety with the lowest WEV value (4.4 mPa.s) showed the best BWG and FCR, and did not differ significantly from the results obtained in the group fed the control diet based on wheat. In general, there was a tendency towards poorer growth rate and feed efficiency with increasing viscosity of grain water extract. However, the correlation coefficient, although high, was insignificant between WEV and BWG or FCR $(r=-0.89$ and 0.77$)$ because of the small number of rye samples tested. The only significant correlation was found between BWG and the WEV/SAX ratio $(r=-0.99)$. Although the ratio of WEV to SAX does not give specific information on the structure of the arabinoxylan $(\mathrm{AX})$, it may indicate that their properties are associated with the degree of substitution in the xylose chain. According to Bengtsson et al. (1992) the viscosities of water extractable $\mathrm{AX}$ solutions were more strongly related to the content of disubstituted xylose residues of higher molecular weight than to the content of monosubstituted xylose units. Nevertheless, the results of the growth trial are in agreement with the earlier findings of Boros et al. (1997) and confirmed that in vitro viscosity assay may be used as a simple preliminary test for determination of the nutritive value of rye for broilers. 
TABLE 3

The effect of enzyme supplementation on dict intake, body weight gain (BWG) and feed to gain ratio (FCR) in broiler chickens fed rye hybrid-based diets

\begin{tabular}{|c|c|c|c|c|}
\hline Diet & Enzymes & $\begin{array}{c}\text { Dict intake } \\
\text { g/chick/7days }\end{array}$ & $\begin{array}{c}\text { BWG } \\
\text { g/chick/7 days) }\end{array}$ & FCR \\
\hline Wheat & - & $144^{\text {ithed }}$ & $90.2^{\mathrm{hx}}$ & $1.60^{c}$ \\
\hline \multicolumn{5}{|l|}{ Rye hybrids } \\
\hline \multirow[t]{2}{*}{$(2713 \times 4475) \times 705$} & - & $132^{\text {bcde }}$ & $84.7^{\mathrm{bcd}}$ & $1.66^{\mathrm{hc}}$ \\
\hline & + & $164(24)^{\mathrm{u}}$ & $121.6(43)^{\mathrm{a}}$ & $1.35(18.7)^{c}$ \\
\hline \multirow[t]{2}{*}{$(1993 \times 4475) \times 2803$} & - & $123^{\text {cte }}$ & $71.2^{\mathrm{cdc}}$ & $1.91^{\text {ih }}$ \\
\hline & + & $153(24)^{\mathrm{ab}}$ & $101.5(43)^{\mathrm{ab}}$ & $1.56(18.3)^{\mathrm{c}}$ \\
\hline \multirow[t]{2}{*}{$(4475 \times 2035) \times 2803$} & - & $117^{\mathrm{de}}$ & $61.1^{\text {de }}$ & $1.98^{\mathrm{a}}$ \\
\hline & + & $147(26)^{\text {abc }}$ & $102.3(67)^{\mathrm{ab}}$ & $1.50(24.2)^{\mathrm{c}}$ \\
\hline \multirow[t]{2}{*}{$(2040 \times 4475) \times 2803$} & - & $105^{\mathrm{e}}$ & $57.2^{\mathrm{e}}$ & $1.95^{\mathrm{a}}$ \\
\hline & + & $154(36)^{\text {at }}$ & $105.6(85)^{\mathrm{ab}}$ & $1.51(22.6)^{\mathrm{c}}$ \\
\hline \multicolumn{2}{|l|}{ Pooled SEM } & 9.6 & 9.1 & 0.10 \\
\hline \multicolumn{5}{|l|}{ Significant effect means } \\
\hline \multirow[t]{2}{*}{ rye hybrids } & - & $119^{b}$ & $68.6^{b}$ & $1.88^{a}$ \\
\hline & + & $154(30)^{\mathrm{a}}$ & $107.8(57)^{\lrcorner}$ & $1.48(21.3)^{\mathrm{b}}$ \\
\hline & Probability & & \\
\hline \multicolumn{2}{|l|}{$\begin{array}{l}\text { Source of variation } \\
\text { grain }\end{array}$} & NS & 0.066 & 0.0727 \\
\hline \multicolumn{2}{|l|}{ enzyme } & 0.00001 & 0.00001 & 0.00001 \\
\hline \multicolumn{2}{|l|}{ grain $x$ enzyme } & NS & NS & NS \\
\hline
\end{tabular}

values in parentheses are the percentage improvements following enzyme supplementation a.b - means within a column with no common superscripts differ significantly at $\mathrm{P} \leq 0.05$ NS - non significant

Despite the significant differences in growth parameters, there were no differences found between rye diets in $\mathrm{AME}_{\mathrm{n}}$ the average value was significantly $(\mathrm{P} \leq 0.001)$ lower than that of control wheat diet ( $2894 \mathrm{vs} 3377 \mathrm{kcal} / \mathrm{kg}$ ) (Table 4). No relationship was observed between $\mathrm{AME}_{\mathrm{n}}$ and $\mathrm{FCR}$ or any physicochemical quality indicators. This study once again shows that in the case of viscous grains, the $\mathrm{AME}_{\mathrm{n}}$ test when concomitantly run with a growth trial does not give results consistent with performance data (Boros et al., 1997). Similar discrepancies were observed earlier by Rose and Bedford (1995) in wheat-based diets and by Boros (1999) in triticale diets. According to Bedford (1996) the reasons stem from a lack of recognition of the differences in intestinal maintenance energy costs placed on the bird through the use of specific ingredients and, more importantly, the role of intestinal microflora in energy and protein utilisation. All these data indicate, therefore, that the measure of AME is not always a good predictor of subsequent bird 
TABLE 4

The effect of enzyme supplementation on apparent metabolisable energy $\left(\mathrm{AME}_{\mathrm{n}}\right.$ ) of diet and grain and apparent protein retention (APR) in broiler chickens fed rye hybrid-based diets

\begin{tabular}{|c|c|c|c|c|}
\hline \multirow[t]{2}{*}{ Diet } & \multirow[t]{2}{*}{ Enzymes } & \multicolumn{2}{|c|}{$\mathrm{AME}_{\mathrm{n}} \mathrm{kcal} / \mathrm{kg} \mathrm{DM}$} & \multirow{2}{*}{$\begin{array}{c}\text { APR } \\
\%\end{array}$} \\
\hline & & diet & grain & \\
\hline Wheat & - & $3377^{\mathrm{a}}$ & $3295^{a}$ & $62.8^{\mathrm{bx}}$ \\
\hline \multicolumn{5}{|l|}{ Rye hybrids } \\
\hline \multirow[t]{2}{*}{$(2713 \times 4475) \times 705$} & - & $2887^{\mathrm{d}}$ & $2654^{d}$ & $60.4^{c}$ \\
\hline & + & $3019(4.6)^{b x}$ & $2840(7.0)^{\mathrm{hc}}$ & $63.7(5.4)^{\mathrm{b}}$ \\
\hline \multirow[t]{2}{*}{$(1993 \times 4475) \times 2803$} & - & $2935^{\mathrm{cd}}$ & $2723^{b}$ & $59.8^{c}$ \\
\hline & + & $3058(4.2)^{\mathrm{b}}$ & $2899(6.5)^{\mathrm{b}}$ & $63.8(6.7)^{\mathrm{b}}$ \\
\hline \multirow[t]{2}{*}{$(4475 \times 2035) \times 2803$} & - & $2887^{d}$ & $2653^{d}$ & $61.0^{\mathrm{bi}}$ \\
\hline & + & $3076(6.5)^{b}$ & $2925(10.2)^{b}$ & $67.5(10.6)^{a}$ \\
\hline \multirow[t]{2}{*}{$(2040 \times 4475) \times 2803$} & - & $2866^{d}$ & $2625^{d}$ & $61.1^{\mathrm{bc}}$ \\
\hline & + & $3021(5.4)^{\mathrm{hc}}$ & $2846(8.4)^{\mathrm{bc}}$ & $67.5(10.6)^{\mathrm{a}}$ \\
\hline Pooled SEM & & 39.8 & 53.9 & 1.0 \\
\hline \multicolumn{5}{|l|}{ Significant effect means } \\
\hline \multirow[t]{2}{*}{ rye hybrids } & - & $2894^{b}$ & 2663 & 60.6 \\
\hline & + & $3044(5.2)^{a}$ & $2878(8.0)^{a}$ & $65.6(8.3)^{\mathrm{a}}$ \\
\hline \multicolumn{2}{|l|}{ Source of variation } & & Probability & \\
\hline grain & & NS & NS & NS \\
\hline enzyme & & 0.00001 & 0.00001 & 0.00001 \\
\hline grain $x$ enzyme & & NS & NS & NS \\
\hline
\end{tabular}

values in parentheses are the percentage improvements following enzyme supplementation and ${ }^{i, b}$ - as in Table 3

performance and relying on this quality indicator alone could be risky in practical feeding. Performance data, particularly FCR data, should probably always accompany AME data if the true feeding value is to be determined.

Supplementation of the rye diets with enzymes containing xylanase and arabinosidase activities markedly ( $\mathrm{P} \leq 0.0001)$ improved diet intake, BWG, FCR, AME and APR values, on average by $30,57,21,5$ and $8 \%$, respectively. In general, the poorer the nutritive value of the rye, the greater the benefit following enzyme addition. The greatest improvement in enzyme addition, approximately $85 \%$, was found in BWG, in chickens fed a diet based on the rye hybrid that showed the highest viscosity and WEV to SAX ratio. Such an improvement has not so far been cited in the literature. This was achieved by supplementation with enzymes not only of xylanase but also of arabinosidase activity and suggests that the mixture may be more effective than a xylanase alone. Since there were no interactions 
between rye hybrids and enzyme additions for productive parameters it means that the effect of enzyme combination was the same on each hybrid. The mixture of these two enzymes conceivably resulted in a relatively high extent of SAX depolimerization in the small intestine as indicated by the three-fold increase in digestibility of SAX in birds fed enzyme-supplemented diets as compared to controls (Table 5). Nevertheless, the digestibility of soluble arabinoxylans was very low, independent of the diet and ranged from 3 to $25 \%$, with an average value around $13 \%$, and was markedly lower than the digestibility of SAX from the wheat diet $(45 \%)$. The difference was especially obvious in the digestibility of SA between unsupplemented wheat and rye diets (43 vs $2 \%)$. On the other hand, wheat TAX were not as well digested as those from rye (10 vs $20 \%$ ). These results highlight the differences in the structure and especially molecular mass of arabinoxylans between these two species of grain, differences that may affect their absorption in the digestive tract of chickens. Alternatively, wheat SAX are may be more easily fermented by the gut microflora.

The shortage of grain supply did not allow us to determine the influence of each enzyme in isolation, but it may be assumed that the efficacy of each enzyme would be not as high as both applied together. Thus, additional studies should be

TABLE 5

The effect of enzyme supplementation on digestibility of soluble and total arabinoxylans in broiler chickens fed rye hybrid-based diets

\begin{tabular}{|c|c|c|c|c|c|c|c|}
\hline \multirow{2}{*}{ Diet } & \multirow{2}{*}{$\begin{array}{l}\text { Enzy- } \\
\text { mes }\end{array}$} & \multicolumn{3}{|c|}{ Soluble $^{1}$} & \multicolumn{3}{|c|}{ Total $^{1}$} \\
\hline & & S.A. & SX & SAX & TA & TX & TAX \\
\hline Wheat & - & 43.37 & 45.62 & 44.61 & 17.52 & 4.34 & 10.10 \\
\hline \multicolumn{8}{|l|}{ Rye hybrids } \\
\hline \multirow[t]{2}{*}{$(2713 \times 4475) \times 705$} & - & 3.18 & 16.82 & 11.69 & 18.85 & 14.88 & 16.68 \\
\hline & + & 16.98 & 23.20 & 20.86 & 23.83 & 21.02 & 22.31 \\
\hline \multirow[t]{2}{*}{$(1993 \times 4475) \times 2803$} & $3-$ & 9.27 & 23.46 & 18.16 & 21.91 & 14.77 & 17.80 \\
\hline & + & 18.12 & 28.68 & 24.74 & 25.86 & 24.83 & 25.26 \\
\hline \multirow[t]{2}{*}{$(4475 \times 2035) \times 2803$} & $3-$ & -2.27 & 6.55 & 3.10 & 28.01 & 14.05 & 20.28 \\
\hline & + & 0.68 & 6.61 & 4.29 & 30.17 & 24.83 & 27.17 \\
\hline \multirow[t]{2}{*}{$(2040 \times 4475) \times 2803$} & $3-$ & -1.27 & 15.16 & 9.11 & 19.64 & 9.41 & 14.05 \\
\hline & + & 2.54 & 16.08 & 11.09 & 24.32 & 15.82 & 17.63 \\
\hline \multicolumn{8}{|l|}{ Main effect means } \\
\hline \multirow{2}{*}{ enzyme } & - & 2.2 & 15.5 & 10.5 & 22.1 & 13.3 & 17.2 \\
\hline & + & $9.6(330)$ & $18.6(20)$ & $15.3(45)$ & $26.0(18)$ & $21.6(63)$ & $23.1(34)$ \\
\hline
\end{tabular}

' SA, SX, SAX - soluble arabinose, xylose and arabinoxylans, respectively

TA, TX, TAX - total arabinose, xylose and arabinoxylans, respectively

values in parentheses are the percentage improvements following enzyme supplementation 
carried out to compare the nutritional effect of these two enzymes applied separately and as a mixture.

Overall, the results of this study showed that much may still be done to improve the nutritive value of rye for broiler chickens. It scems that such an improvement can be achieved by selection and breeding of rye varieties with a lower WEV and SAX content together with the appropriate choice of feed enzymes. These enzymes should hydrolyse the polysaccharides and therefore significantly lower viscosity of gut digesta and increase the retention of nutrients.

\section{ACKNOWLEDGMENTS}

We wish to express our sincere appreciation to B. Rek-Ciepła, A. Jankowska, and E. Durawa for their excellent technical assistance.

\section{REFERENCES}

AOAC, 1990. Association of Official Analytical Chemists. Official Methods of Analysis. 15th Edition. Arlington, Virginia, USA

Asp N-G., Johansson C-G., Hallmer H., Siljeström M., 1983. Rapid enzymatic assay of insoluble and soluble dietary fibre. J. Agr. Food Chem. 31, 476-482

Bedford M.R., 1996. Interaction between ingested fecd and the digestive system in poultry. J. Appl. Poultry Res. 5, 86-95

Bedford M.R., Classen H.L., Campbell G.L., 1991. The effect of pelleting, salt, and pentosanase on the viscosity of intestinal contents and the performance of broilers fed rye. Poultry Sci. 70, 1571-1577

Bengtsson S., Åman P., 1990. Isolation and chemical characterization of water-soluble arabinoxylan in rye grain. Carbohyd. Polym. 12, 267-277

Bengtsson S., Andersson R., Westerlund E., Åman P., 1992. Content. structure and viscosity of soluble arabinoxylans in rye grain from several countries. J. Sci. Food Agr. 58, 331-337

Boros D., 1998. Tolerance of broiler chickens to dietary soluble rye arabinoxylans. J. Anim. Feed Sci. 7, 323-331

Boros D., 1999. Influence of R genome on nutritional value of triticale for broiler chickens. Anim. Feed Sci. Tech. 76, 219-226

Boros D., Madej L., Jagodziński J., 1997. Perspectives of selection for better nutritive quality of rye I. Viscosity of grain water extract as an index of nutritive value of rye for broiler chickens. Plant Breed. Seed Sci, 41, 81-89

Boros D., Marquardt R.R., Guenter W., 1995. Rye as an alternative grain in commercial broiler feeding. J. Appl. Poultry Res. 4, 341-351

Boros D., Marquardt R.R., Slominski B.A.,Guenter W., 1993. Extract viscosity as an indirect assay for water-soluble pentosan content in rye. Cereal Chem. 70, 575-580

Campbell G.L., Teitge D.A., Classen H.L., 1991. Genotypic and environmental differences in rye fed to broiler chickens with dietary pentosanase supplementation. Can. J. Anim. Sci. 71, 1241-1247 
Duncan D.G., 1955. Multiple range and multiple F tests. Biometrics 11, 1-42

Girhammar U., Nair B.M., 1992. Certain physical properties of water soluble non-starch polysaccharides from wheat, rye, triticale, barley and oats. Food Hydrocoloid. 6, 329-343

Hill F.W., Anderson D.L., Renner R., Carew L.B. Jr., 1960. Studies of the metabolizable energy of grain and grain products for chickens. Poultry Sci. 39, 573-579

Madej L., Raczyńska-Bojanowska K., Rybka K., 1990. Variability of the content of soluble nondigestible polysaccharides in rye inbred lines. Plant Breed. 104, 334-339

Marquardt R.R., Boros D., Guenter W., Crow G., 1994. The nutritive value of barley, rye, wheat and corn for young chickens as affected by use of a Trichoderna reesei enzyme preparation. Anim. Feed Sci. Tech. 45, 363-378

McGinnis G.D., 1982. Preparation of aldononitrile acetates using N-methylimidazole as catalyst and solvent. Carbohyd. Res. 108, 284-292

Rose S.P., Bedford M.R., 1995. The relationship between the metabolizable energies of wheat and the productive performance of broilers. In: Proceedings of World Poultry Science Association, UK Branch Spring Meeting, Scarborough (UK), pp. 98-102

Vinkx C.J.A., Delcour J.A., 1996. Rye (Secale cereale L.) arabinoxylans, A critical review. J. Cercal Sci. 24, 1-14

Vinkx C.J.A., Delcour J.A. Verbruggen M.A., Gruppen H., 1995. Rye water-soluble arabinoxylans also vary in their contents of 2-monosubsituted xylose. Cereal Chem. 72, 227-228

Vinkx C.J.A., Reynaert H.R., Grobet J., Delcour J.A., 1993. Physicochemical and functional properties of rye nonstarch polysaccharides. V. Variability in the structure of water-soluble arabinoxylans. Cereal Chem. 70, 311-317

\section{STRESZCZENIE}

Wplyw lepkości wodnego ekstraktu i egzogennych enzymów na wartość pokarmową mieszańców żyta dła kurcząt brojlerów

Kurczęta brojlery karmiono dietami zawicrającymi ziarno 4 mieszańców żyta różniących się lepkością wodnego ekstraktu ziarna (WEV). Diety były przygotowane bez lub z dodatkiem enzymów degradujących arabinoksylany celem określenia wpływu lepkości ziarna oraz dodatku ksylanazy $\mathrm{i}$ arabinozydazy na przyrost masy ciała, zużycie paszy, energię metaboliczną ( $\mathrm{AME}_{\mathrm{n}}$ ), pozorną retencję białka (APR) i strawność arabinoksylanów u młodych kurcząt brojlerów. Dieta pszenna była użyta jako kontrola. Usunięcie szkodliwego wpływu rozpuszczalnych arabinoksylanów (SAX) żyta poprzez dodanie obu enzymów istotnie poprawiło spożycie paszy, przyrost masy ciała oraz zuźycic paszy, średnio o 30,57 i $21 \%$, odpowiednio w porównaniu z wynikami uzyskanymi na ptakach karmionych dietami nie uzupełnionymi tymi enzymami. Wydaje się, że tak wysoka poprawa wskaźników produkcyjnych była wynikiem zwiększenia AME $\mathrm{E}_{\mathrm{n}}$ i APR (o 5 i $8 \%$ ) oraz strawności rozpuszczalnych i ogólnych arabinoksylanów (o 45 i $34 \%$ ). Podsumowując należy stwierdzić, że im gorsza była wartość pokarmowa testowanego żyta tym większą poprawę można uzyskać stosując dodatek odpowiednich enzymów paszowych. Wyniki tych badań wskazuja, żc można zwiększyć wartość pokarmową żyta dla kurcząt brojlerów przez selekcję i hodowlę odmian żyta o obniżonej WEV i zawartości SAX w ziarnie oraz dodatek odpowiednio dobranych enzymów, które mogą hydrolizować SAX, obniżać lepkość treści jelitowej i zwiększać wchłanianie składników pokarmowych. 